\title{
SARS-CoV-2 infection as a risk factor for herpesviridae reactivation: consider the potential influence of corticosteroid therapy
}

\author{
Patrick M. Honore*, Leonel Barreto Gutierrez, Luc Kugener, Sebastien Redant, Rachid Attou, Andrea Gallerani \\ and David De Bels
}

We read with great interest the recent article by Le Balc'h et al. who concluded that their results suggest that SARSCoV-2 infection could be a risk factor for Herpesviridae reactivation [1]. We would like to make some comments. Glucocorticoid treatment increases the risk of opportunistic infection [2]. Infections that can arise during glucocorticoid use, and for which preventative measures can be taken, include reactivation of Herpesviridae that can lead to herpetic pneumonia [2]. In the study of Le Balc'h et al. [1], 44\% of patients in the Herpesviridae reactivation group received corticosteroids, compared to only $20 \%$ of patients in the non-reactivation group. Although the difference did not reach statistical significance due to the low number of patients, the difference is still notable and may explain, at least in part, the difference in Herpesviridae reactivation between the groups. Herpesviridae reactivations occur easily after high-dose steroids and may lead to fatal disease [3]. Possible infectious complications as a result of Herpesviridae reactivations should be considered in patients who receive high-dose glucocorticoid treatment amounting to more than $420 \mathrm{mg}$ of steroid over 4 weeks [4]. This is equal to a daily dose of $52.5 \mathrm{mg}$ of prednisolone [4]. The dose of steroid and the duration of treatment are not reported in the Le Balc'h et al. study [1]. Given that a dose of $52.5 \mathrm{mg}$ of prednisolone is equal to $8 \mathrm{mg}$ of dexamethasone, the dose used in the RECOVERY trial (6 mg) [5] may not increase the risk

*Correspondence: Patrick.Honore@CHU-Brugmann.be

ICU Department, Centre Hospitalier Universitaire Brugmann-Brugmann

University Hospital, Place Van Gehuchtenplein, 4, 1020 Brussels, Belgium of reactivation of Herpesviridae. However, perhaps even the regimen of $6 \mathrm{mg}$ dexamethasone for 10 days that was used in the RECOVERY trial could result in Herpesviridae pulmonary reactivation when given in the context of prolonged mechanical ventilation and concomitant bacterial sepsis.

\section{Acknowledgements \\ None. \\ Authors' contributions \\ Funding \\ None. \\ Availability of data and materials \\ Not applicable.}

PMH, SR, DDB designed the paper. All authors participated in drafting and reviewing. All authors read and approved the final manuscript.

Ethics approval and consent to participate

Not applicable.

\section{Consent for publication}

Not applicable.

\section{Competing interests}

The authors declare to have no competing interests.

Received: 12 September 2020 Accepted: 16 October 2020 Published online: 22 October 2020

References

1. Le Balc'h P, Pinceaux K, Pronier C, Seguin P, Tadié JM, Reizine F. Herpes simplex virus and cytomegalovirus reactivations among severe COVID-19 patients. Crit Care. 2020;24(1):530. https://doi.org/10.1186/s13054-02003252-3.

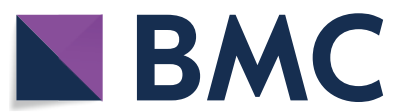

(c) The Author(s) 2020. Open Access This article is licensed under a Creative Commons Attribution 4.0 International License, which permits use, sharing, adaptation, distribution and reproduction in any medium or format, as long as you give appropriate credit to the original author(s) and the source, provide a link to the Creative Commons licence, and indicate if changes were made. The images or other third party material in this article are included in the article's Creative Commons licence, unless indicated otherwise in a credit line to the material. If material is not included in the article's Creative Commons licence and your intended use is not permitted by statutory regulation or exceeds the permitted use, you will need to obtain permission directly from the copyright holder. To view a copy of this licence, visit http://creativecommons.org/licenses/by/4.0/. The Creative Commons Public Domain Dedication waiver (http://creativeco mmons.org/publicdomain/zero/1.0/) applies to the data made available in this article, unless otherwise stated in a credit line to the data. 
2. Pines N, Tsabari R, Kerem E, Reiter J. Herpes simplex virus pneumonia in an immunocompetent child on corticosteroids for acute wheezing. PediatrEmerg Care. 2018. https://doi.org/10.1097/PEC.000000000000151 9.

3. Osterman A, Ruf VC, Domingo C, et al. Travel-associated neurological disease terminated in a postmortem diagnosed atypical HSV-1 encephalitis after high-dose steroid therapy - a case report. BMC Infect Dis. 2020;20(1):150. https://doi.org/10.1186/s12879-020-4859-5.

4. Minderhoud TC, van Meer MPA, van Thiel RJ, den Hoed CM, van Daele PLA, Schurink CAM. Infecties bij gebruik van glucocorticoïden [Infections during glucocorticoid use]. Ned Tijdschr Geneeskd. 2018;162(37):D2215.
5. RECOVERY Collaborative Group. Dexamethasone in hospitalized patients with Covid-19-preliminary report. N Engl J Med. 2020. https://doi. org/10.1056/NEJMoa2021436.

\section{Publisher's Note}

Springer Nature remains neutral with regard to jurisdictional claims in published maps and institutional affiliations.
Ready to submit your research? Choose BMC and benefit from:

- fast, convenient online submission

- thorough peer review by experienced researchers in your field

- rapid publication on acceptance

- support for research data, including large and complex data types

- gold Open Access which fosters wider collaboration and increased citations

- maximum visibility for your research: over 100M website views per year

At BMC, research is always in progress.

Learn more biomedcentral.com/submissions 